\title{
IMPACT OF PROPER QUESTIONING IN TEACHING AND LEARNING
}

Osmonbaeva Zhypargul Akunbaevna, senior instructor of the chair of teaching English methods, Master in Education, Osh State University, Faculty of World Languages and Cultures, Osh city, Kyrgyz republic

Pakhirova Damira Isirovna, senior instructor of the chair of German language, Master of linguistics, Osh State University, Faculty of World Languages and Cultures, Osh city, Kyrgyz republic

\section{DOI: https://doi.org/10.31435/rsglobal_conf/25022021/7422}

Abstract. The paper attempts to share some of the experiences regarding the proper questioning and literature review on this topic. The paper is based upon the outcomes of proper questioning in teachers' lessons and impacts of those questions on their teaching and students' learning.

Main importance is given to teacher's role in proper questioning in teaching English. Significance of the study is questioning can be used in different types of classroom and it helps students develop thinking skills, language skills and shaped closed relation and interaction between student-to- student and student-to- teachers.

Interview was used for data collection. The purpose of using interview was to listen to the views on the proper questioning which can impact on their teaching and students' learning.

Findings suggest that teachers' often usage of different types classroom questioning which demand higher order thinking answers can be the indicative of a change in their approaches to and attitudes towards teaching and students learning.

Keywords: Impact, questioning, proper, higher order, low-level, reasonable.

Introduction. "Don't just teach your children to read... Teach them to question what they read, teach them question everything". George Carlin [3]

As George Carlin mentioned above, we adults and children need to know how formulate a proper question and think of what do we read and why do we read? It is believed that asking proper questions shows the intellect of the person who asks the question, because a person who knows how to formulate better questions, they are skilled to questioning.

If children can do something for purpose and reasonably, they can ask question each and everything why they do that?

Especially, young children come up with a hundred of questions in a day. They ask the same questions as; what is it? Why do they do? Where do the ants go? Why elephant has a long trunk? etc. There is a popular belief that children learn from asking questions and questions help them find the answers.

The purpose of choosing this theme that many teachers spend almost most of the time asking low-level cognitive questions. These cognitive questions concentrate on factual information that can be memorized example; what year did the Great patriotic War begin? Or who wrote the "White Streamer"? It is believed that this type of questions can limit students to acquire a deep, elaborate understanding of the subject matter.

Teachers make mistakes while asking questions that they ask vague questions. For example; what did you think of that plane which has fallen recently? These kinds of questions seemed trick and too abstract for children of their ages and students don't know how to answer.

Therefore, the purpose of writing this paper is to investigate teachers views about questioning experiences in their lessons in order to know whether they use proper questions in their lessons or not. If they use proper questions then to identify how those questions can effect on learning and teaching also is one of the main purposes of the paper. Since many years teaching was required to use multiple choice tests for evaluating students' achievement in the classes in my context. The experiences revealed that using all the time multiple questions make students lazy and without thinking they can cheat in exams. Recently in the last few years the authority demanded us to develop questions which can make students think deeply and differently. 
Referring to some literature sources the word question is defined by Victoria Neufeldt \& David B. Guralnic in Webster's New World College Dictionary definition [10, p.1391] "Question "is asking, inquiry and something is to be asked interrogative sentence as in seeking to learn and testing another's knowledge. As we have seen, questioning leads to search knowledge which is needed to learn and tests one's knowledge.

Ghuskas K. [4, p.245-48] mentioned the importance of questions in motivating student into English lesson. What things can evoke students' curiosity? He claimed that the answers depend on the questioning itself. Therefore, for getting reasonable answers from learners' questions should be designed properly.

David Russell argues in Ghuskas K. [4, p.245-48] questions are used to stimulate creative thought and leads to new ideas, solutions and to enhance the quality of one's life. He argues here that the adequate use of questions will increase students' knowledge on the subject matter.

Teachers use many techniques and different activities to involve students to their lessons. Chaudron [1, p.26] discusses that with those different strategies teachers ask questions is the most important, because it helps students hold their attention, contribute to students' classroom routine.

Similarly, teachers use different questions at the beginning of the lesson use weather forecast questions, during the lesson, after the lesson to check students' text comprehension and to elicit students' ideas.

\section{Proper Questioning can effect on teachers' teaching and students' learning}

There many discussions and experiments were done by educators concerning using questioning in teaching English as a foreign and as second language classrooms. Educators find very important for teachers to use the skill of asking questions. For instance, Ornstein [8, p.71] claims that "the essence of good teaching is related to good questioning". Questions seem as a stimulator students' thinking and enhance their class participation.

Kloss [6, p.245] reports that 93 percent questions asked by elementary and secondary teachers very lower order level of comprehension, because of it 88 percent of the students' answers were also lower level of cognitive skills.

Therefore, concerning about above issues that 88 percent of the students' low level of thinking can make teachers ask much more higher-level order questions which can demand more thinking and analyses rather than asking lower-level questions. So, the scientific authors prove in their own experiences the truth of the effectiveness of proper questioning method in guiding students' thinking. So, the impact of questioning method to teach has been valued for centuries.

In addition, to that questioning has a positive impact on students' learning foreign languages, because it leads to discussion. Discussion can help students' give their own opinions well and it can give a chance them to learn from each other during the classroom talk. At the result, students can improve speaking skills through discussion and they can express freely whatever they think is right.

In any way, there is some limitations that as asking questions is a human work, not all the time teachers cannot prepare skillful questions.

Another limitation is many questions which prepared and asked by teachers in classes are based on memorized learning and in a lowest level which doesn't demand any cognitive thinking. It is believed that questions are asked by the teachers need to depend on the instructional objectives of the lesson.

Lindquist [7, p.16-18] suggests teachers the followings help of asking students more good questions in their classrooms. For this:

-teachers need to prepare and ask knowledge-based questions ability recognizing, recalling

-use terms like as how, why, what to encourage students' thinking

-prepare questions in advance

- ask questions in a logical sequence

-ask specific questions that students can answer slowly

- request that students repeal the teachers' question before answering

-when one student is asked a question, have another student repeat the question before a response

-allow students to converse with each other in a directed manner after a question is asked or answered

-request students their own questions fully and specifically

-name specific students in a random order to respond questions

-provide adequate waiting time after naming respondent (3to 5seconds) 
Effective questions.

Gray. D. Borich [5.p.194] defines that if questions should to evoke a response that actively engage a student in the learning process, then it is an effective question. Borich continues saying that questions are tool for helping to bridge the gap between the teacher's presentation of content and the students understanding of the tasks and it promotes thinking.

Gall says in Gray. D. Borich that not all questions will engage students actively in the learning process. Dunkin and Biddle and Martin discuss in Gray. D. Borich teachers who ask questions requiring analyses, synthesis, and evaluation their effects show up on immediate tests of student achievement [5, p.198].

\section{The teacher's role in questioning.}

We, teachers talk about the second or foreign language classroom and put aim of how to motivate our students to talk and formulate right questions on the given task in the classroom. The most role of using teachers' questions is to organize students' thoughts and generate ideas and to elicit students' knowledge about the subject matter. (Richards, 2000)

Dillion [2, p.540-551] has pointed out that the social rules of the classroom make students' questions in appropriate. He said if questions become powerful learning catalysts and provide excellent tools for the students to learn.

\section{Open Ended questions.}

It is required that we, teachers need to formulate questions which could make students challenge and make them think deeply. An open-ended question was seemed to challenge our students to think more deeply might look like the following. This kind of questions like, if you won million dollar somehow would your life be different from now? will benefit to students. Therefore, students need to be encouraged to think deeply. Here we have to ask more elaboration questions like, can you elaborate more? Why do you think it is necessary? Are there any other ways to solve the problem? These types of questions make students think and speak more.

\section{Support students' ideas.}

When students tell their own arguments to questions/ problems teachers need to support them, because each has his/her own ideas and they believe they are right in their own ways. In this case, teachers should support them to tell their arguments and beliefs. They should not discourage them saying that they are not right. Instead, teachers give them time to reason their thoughts.

Methodology. For collecting teachers' views about asking proper questions interview (see appendix A) was used. In the process of the study the interview allows teachers to give their own views and experiences in using proper questions in their lessons. There were 6 teachers participated in this study. 3 young teachers and 3 experienced teachers of my colleagues. The average age of teachers 40,52 , and one experienced teacher she is 68.

Teachers of Kyrgyz, German, English languages were interviewed. Those teachers were informed beforehand and ensured of the confidentiality of their responses. For this, in each interview, responses were numbered, for example, teacher 1 used number 1-AT1. Due to some efficient reasons interview was taken through phone.

This study was to investigate how the proper questioning can impact on teaching and learning. According to the interview results it was revealed that some teachers use questioning for warming up activity and teachers use games to practice the questioning and remembering, thinking skills. The game was called "Who am I"? In this game through asking right questions student can find his/ her name. However, this game seemed to be used for young students and question was low order.

Teachers realized that answer depends on what is question itself, therefore, they believe that learning to formulate very thoughtful questions is demanding. Most of the time young teachers used to ask questions which need easy answer or yes, no answer. However, experienced teachers believe that those types of yes/no answer not answer at all, because the answer seemed to be known to everybody. Even students don't make their head pain to the questions like above. It was clear that to get satisfactory reply from our students in the first place, teachers need to formulate appropriate questions.

During interview with teachers, it was revealed that some students' way of thinking and their content knowledge were in a high level, in contrast there were some students even cannot express their thoughts well. Teachers said that they formulate the questions according to the students' level and their age.

Teachers' experiences indicated that the questioning makes close relationship between teachers and students and it also helps assess the students' knowledge of the content. 
Teacher AT1 responded that "Questioning plays important role in her teaching and learning, because she uses questioning in every lesson for checking home task, for making students think deeply. Teacher AT1 said, she uses "Inference questioning" example, "She had tears on her eyes". When she asks this type of questions from students, she continues asking further questions, such as: Why she had tears? Students can predict in different ways; one student might say that she might has eye sore. Another student might respond that she might be sad. Teacher AT1 confirmed that predictions, guessing, different answers inference questions can help students develop their deep thoughts.

Teacher AT1 continued her speech that she avoids easy questions, because some students can answer yes/no even, they cannot understand the content, on the other hand, why questions push students think, enable to speak and give a chance their own ideas.

Teacher AT2 responded that she uses questioning for eliciting student opinions about particular topic. She uses at the beginning to remind previous activity, after presentation for checking students' understanding and to wrap the lesson. She said that sometimes questioning is not effective when students cannot revise, remember answers. If her students cannot answer questions, she reformulates the question, makes questions easy and simplify.

Teacher AT3 said that questioning is a part of human communication for getting information about the issues someone interested in. She can use in different stages to identify the learners' knowledge of the new material, comprehension and result of the lesson. Nevertheless, she mentioned that some students prefer short yes/ no answers.

She said that mostly "Why" questions as where does it happen, why it happened what would you do in that situation give more meaningful responds. Questions help to check, clarify students' understanding of the material. It can also raise students' interest, motivate, engage them to the lesson, push them to participate in discussions. Sometimes questions are not made to the point or students don't understand the topic. In this case, teacher remembers if proper questions are not made, students don't understand the topic.

Teacher AT4 asks questions for knowing something or getting for necessary information. She uses questions at the beginning, before new theme, "What do students expect from this or that theme? and What do they quess?". When she asks questions she said that she keeps in her mind students' level of knowledge. She continued saying that when students answered to those questions, at that time new questions appeared. She mentioned that most of the time questions related to the new theme. Questions like why? for what? what does the author want to say with this? what is the author's purpose? What is your opinion of the text? Positive and negative characters? What would you do if you were in the character's place?

Teacher AT4 said that, questions push students to tell their ideas and if students responds are correct teachers are happy. If students cannot answer she can help them to answer. She said that effect of questioning is that give a chance to each student can tell his/her ideas. One more effect it helps teachers to check whether student understand the theme or not.

Teacher AT5 responded that "Question is activity or process of asking something". It can develop students thinking. Give immediate feedback on students' understanding which help teacher modify teaching. She asks questions after the text, because according to her questions can review, restate emphasize or summarize the text is important. She uses closed, open, probing questions and sometimes rhetorical questions. She responded that those kinds of questions help students think and reflect, provide opinions and feelings and take control of the conversations.

Another teacher AT6 responded that questioning is demanded thing to know something. "The purpose of asking is different, first, to solve one issue, for asking permission, request, to reinforce the theme". She said that they use questions in everyday life, in the lessons, social place to know answers, unknown things wanted to know the answers. She replied that if material is unknown for them they have difficulties in questioning. She asks mixed questions factual and logical questions, because one can prove the material and second one develops logical thinking. She values the proper questioning, because questions give a good effect can reinforce the materials learnt in the lesson. She asks all other students to know the right answer, if they don't know answer she could help them through explaining the content.

Results. The result of the study indicates that teachers' views on the proper questioning is considered beneficial both teachers and students of any language learners. Even teachers ask questions in a different way, they have the same purposes of asking them. The study also proved that it had been experimented many times that proper questioning should recognize wide possibility of thought. Setting proper questioning needs to be directed toward learning and analyze, evaluate ones thinking. 
According to the result of the study asking the proper questions have showed apparent impact on the teacher's teaching md students' learning. Teachers participated in the study believed that asking proper questions help teachers identify students' learning interests in the subject and questioning help improve teaching and learning the task.

Conclusions. In the present study it was discovered that a proper questioning helps to improve teachers' teaching and students' learning. The result of the study indicates that for teaching any language using proper questioning method is considered beneficial both teachers and students of English language learners. So, teachers need to prepare questions which make students challenge, think deeply, because the study showed that questions are considered a part of learning and a part of life. As it was mentioned in introduction part that asking proper questions shows the intellect of the person.

\section{REFERENCES}

1. Claudron. C. (1988). Second Language Classrooms; Research on Teaching and Learning. Cambridge, UK; Cambridge University Press

2. Dillion, J. T. (1982). Cognitive correspondent between question/statement and response. Educational Research Journal 19; 540-551

3. George Carlin (https://www.george.carlin.com/

4. Ghuskas. K. (2003). Improving Classroom questions: A Teacher guide to Increasing student motivation/ Participation and high level thinking (p5-24) Bloomington, Indiana

5. Gray.D. Borich (1988). Effective Teaching Methods, Merrille Publishing Co 193p.

6. Kloss.R.J.(1988). Toward asking the right questions. The beautiful, the pretty, and the messy ones. The Clearing House 61; 245-48

7. Lindquist, M.M. (1988). Assessing through questioning. Arithmetic Teacher 35: 16-18

8. Ornstein. A.C. (1987), Questioning: the essence of good teaching. NASSP Bulletin 71: 71-79

9. Richards, J. C. (2000). Reflective Teaching in Second Language Classroom. Cambridge, UK; University Press.

10. Victoria Neufeldt \& David B. Guralnic (1997). Webster's New World College Dictionary. (1391p). Macmillian USA.

\section{Appendix A}

Interview Questions (time duration for each teacher is $5 \mathrm{~m}$ )

1. What does questioning mean to you?

2. What is the purpose of asking questions?

3. When do you use questioning in teaching?

5. What challenges to you face in using questions?

7. What kind of questions do you use? and Why?

8. What effect can the questions have on your lesson?

9. What does it imply if your questions are not answered as expected?

10. Is there anything else you would like to add?

Thank you very much for responding interview questions! 